devoted to a further restatement of Nachmanson's views on the general role of acetylcholine in nerve impulse propagation. This particular controversy is too well known to require additional comment here. The immediately subsequent chapters (Tauc and Grundfest) deal with chemical transmitter action in a number of excitable systems and, in typically clear fashion by Grundfest, with the general electrophysiology of the specialized input membrane in excitable cells.

The general relationships between sensory intensity and stimulus analysis are well dealt with by Lipetz and Stevens; the latter presents a stimulating discussion of the Weber-Fechner hypothesis and more recent power function analyses to correlate sensory intensity analyses. Two chapters deal with visual perception: that by Cone and Pak deals very adequately with the origin of and basis of the early receptor potential and Feinleib and Curry discuss phototaxis in plants. As these authors note, the phototactic system may represent a very simple receptoreffector relationship which is, despite past failures, well suited for a complete input and output analysis. The recent discovery of retinal bound to an opsinlike protein in Halobacterium holobium (D. Oesterhelt and W. Stoeckenius, Nature New Biology, 233, 149; 1971) and its similar orientation in the membrane (A. E. Blaurock and W. Stoeckenius, Nature New Biology, 233, 152; 1971) to that in vertebrate retinas suggests the validity of examining simpler biological systems.

I have one major criticism of this book: in a series of topics all of which relate to the cell membrane in some respect it seems an oversight not to have included a specific chapter on the structure and function of cell membranes. There are a number of minor misprints but these do not detract from the high quality of the book. Its price is unfortunately too high to place it in the hands of many individuals. This is a pity, for the book deserves wide circulation. It is an excellent introduction to the proposed series and editors and authors alike are to be congratulated. Subsequent volumes will be eagerly anticipated.

D. J. Triggle

\section{Biochemical Evolution}

Biochemical Evolution and the Origin of Life. Edited by E. Schoffeniels. (Proceedings of the International Conference on Biochemical Evolution.) (Molecular Evolution II.) Pp. xiv + 398 . (North-Holland: Amsterdam and London, 1971.) $£ 8.40$.

THrs volume contains papers on a variety of topics in speculative and comparative biochemistry. They range from careful statistical studies of the rate of evolution of protein sequences to highly speculative histories, for example of the evolution of metabolic pathways. Some of the papers are excellent, but others are of doubtful value; they provide a good sampling of the field, both with respect to subject matter and quality.

It is clear that the students of protein sequences have many more data on which to base their theories than those who work on other branches of biochemical evolution. The paper by Margoliash, Fitch and Dickerson provides a definitive summary of the conclusions that can be drawn from the extensive series of cytochrome c sequences that have been determined so far. Other interesting papers deal with fibrinogen and immunoglobulin sequences.

The evolutionary biochemistry of small molecules is a much more difficult subject. However, it is at least as interesting, since it provides the only hope of understanding evolution in the period before the major outlines of biochemistry became fixed. Unfortunately, the law of pure cussedness applies in this area: the more primitive the process, the more difficult it is to say anything definite about its evolution. The phosphagens and phosphagen kinases must be comparative newcomers to the biological scene; Watt's discussion of the subject is fairly convincing. Energy production, on the other hand, must be a very primitive process; Broda's interesting treatment of bioenergetic evolution raises as many questions as it answers.

The expert will encounter some new material in this book and much that he has seen before. The general reader should find it a useful introduction to the subject.

L. E. Orgel

\section{Biochemical Text}

Cellular Biochemistry and Physiology. By N. A. Edwards and K. A. Hassall. Pp. xiv+442. McGraw-Hill: Berkshire, September 1971.) £3.95.

I REMEMBER a friend who was a physicist telling me that his initial test of the value of a dictionary was to look up the entry for "entropy". As might be expected, I tend to look first at the preface of a textbook of biochemistry and then at the chapter on the biosynthesis of proteins.

In the case of the present book I followed this scheme with rather disastrous results. I was with the authors so far as their aim was concerned, for I am sure that many students like their biochemistry to be based on cell physiology and ultrastructure. The chapter entitled "Polynucleotides and Protein Synthesis" is, however, an awful mess and inakes one wonder whether the authors really understand their subject. A typical statement is (page 346): "Under normal conditions, ribosomes not aggregated in this way make little or no protein although, in the presence of an excess of messenger RNA, single ribosomes synthesize protein quite adequately". Their explanations of the structure of DNA and RNA, the way in which Kornberg polymerase effects the synthesis of DNA, and the steps in the attachment of amino-acid to tRNA, to mention just a few points, are very confusing. It really hurts to see such a beautiful story spoilt in this way.

The first chapter on the cellular basis of life would hardly encourage a student to read on, but if he did he would get to proteins, peptides and amino-acids. There is an amazing diagram showing amino-acids hanging from a thread followed by Table 2-1 giving tests for amino-acids (Sakaguchi, Millon and so on). The latter is just the kind of material the authors promised to exclude. The major considerations that led to the concept of the $\alpha$-helix are not mentioned and Fig. 2-8 is original but not helpful. Do we really have to speculate that the tertiary structure of a protein is the inevitable consequence of the primary structure?

In the chapter on mitochondrial electron transport and oxidative phosphorylation, instead of explaining the objective of the whole business, followed by redox potentials, these matters are left to be described relatively late in the chapter. What happened to "fumarate" in Fig. 6-1? The book ends with a "systematic classification of enzymes" and a very poor list of references.

The authors had a worthwhile objective but in my view they have failed. The book is not to be recommended to students, but we need not be too unduly worried, for it seems very unlikely that a student wanting an elementary text would pay $£ 3.95$.

\section{P. N. CAMPBELL}

\section{Estuarine Ecology}

Ecology of Estuaries. By Donald S. Mclusky. Pp. viii $+144+8$ plates. (Heinemann: London, October 1971.) f1.60.

ESTUARIES are complex and variable environments. A recent symposium on estuaries held in America resulted in a volume containing more than 700 pages, with little overlap in the subject material of the various authors. In a book aimed at sixth formers and first year university students, Dr McLusky has made a brave attempt to provide a concise account of the ecology of estuaries in less than 150 pages. I think 